\title{
The Role of Environmental Law Education for Sustainable Development
}

\author{
Hanna Audzei ${ }^{\mathrm{a}}$
}

\begin{abstract}
National imperative of sustainable development is a strategy that combines into one social, economic and environmental policies. First of all the environmental legal education should aim to prepare people for life in an innovative type of society. To achieve this goal of environmental and legal education we should be reoriented to form a human ecological and legal culture and ecoinnovative type of legal thinking and a willingness to innovative type of environmental and legal action. The successful solution of this and other challenges requires science foundation, including environmental law science.
\end{abstract}

Keywords: law, environmental legal education, sustainable development, environmental safety, ecology, responsibility, ecological culture, legislation

\section{Introduction}

The transition to sustainable development is recognized at the global level by overcoming the negative trends associated with changes in the quality of the socionatural environment as a result of multidimensional activities of an ever-growing global society.

Ecological security has become an increasingly important development factor in all areas of the state in contemporary world ${ }^{1}$.

In the transition to sustainable development, a new type of public relations emerges, which is integral in nature, associated with the need at various levels (global, regional, national and local) to support the development of society, in which the growth of the quality of life of each individual and society as a whole is combined with biospherecompatible activities in various areas of public life.

Law - understood in the conventional sense of official state law-has come to be widely accepted as a central vehicle for environmental protection, because of its ability to create authoritative standards and decision-making procedures for land use planning, pollution control and nature conservation, among many other elements of modern environmental governance ${ }^{2}$.

Sustainable development as a doctrinal concept has long been the master of the minds of scientists. However, a full-fledged transition to sustainable development will be possible only in the case of legal consolidation at various levels of definition, general and particular principles, objects of regulation, indicators (criteria), etc. sustainable

${ }^{1}$ Elaine Nevin Education for Sustainable Development Education and development, 2008, № 6.

2Stepan Wood, Benjamin J. Richardson Environmental Law for Sustainability https://digitalcommons.osgoode.yorku.ca/scholarly_works/?utm_source=digitalcommons.osgoode.yorku.c a\%2Fscholarly_works\%2F337\&utm_medium=PDF\&utm_campaign=PDFCoverPages 
development, as well as the formation of interstate and state management structures that are able to effectively implement a set of administrative, economic and information management methods aimed at achieving a given quality level of sustainable development.

The concept of sustainable development emerged as a response to a growing concern about human society's impact on the natural environment ${ }^{3}$.

The transition to sustainable development is possible only with the cumulative solution of a multitude of environmental problems, the awareness of which began with the world community in the middle of the last century. As a result of this awareness, a whole branch of public international law has emerged, combining international legal norms governing relations between states and other subjects of international environmental law, which is a transition to international sustainable development law. That is underlined in UN documents.

The principle of sustainable development occupies a privileged position in the European legal order ${ }^{4}$.

One of the main directions of the transition of the Republic of Belarus to sustainable development is the formation of an effective system of promoting the ideas of sustainable development and the creation of an appropriate system of education and training. In the implementation of this direction, a large role is given to environmental education in general and environmental legal education in particular. And it is no coincidence. The growing environmental crisis and the global threat to the future of civilization objectively push environmental education to a priority in modern social transformations aimed at the survival of humanity and the preservation of the biosphere, that is, sustainable development.

\section{Discussion}

The problem under study goes beyond the limits of environmental legislation. The principle of sustainable development should be reflected in all normative legal acts, on the basis of which it is ensured sustainable development in the Republic of Belarus, namely in the areas of economic, social development and ensuring the environmental safety of society.

This approach shows that the legal framework for sustainable development should be implemented on a systematic basis.

As noted in the National Strategy for Sustainable Socio-Economic Development of the Republic of Belarus for the Period up to 2020 (hereinafter referred to as NSDS), the national imperative of sustainable development, or a mandatory requirement for a country, a nation as a whole, is to actively and constructively participate in the global process transition to sustainable development, to define the goals and mechanisms of the country's development through the formulation of a sustainable development strategy that integrates social, economic and environmental policies into one whole, integrating

${ }^{3}$ Avdej A.G. On the legal environmental security of the member states of the Eurasian Economic Union https://elibrary.ru/item.asp?id=27505984 Accessed 05/03/2019

${ }^{4}$ Luis A. Avilés Sustainable Development and the Legal Protection of the Environment in Europe /https://pdfs.semanticscholar.org/3fe7/83b8331eb3a0fd5b6a57a7cdcdfc1c03d3f6.pdf 25/05/2019 
efforts of a nation to achieve economic efficiency, social justice and environmental security.

The conceptual core of the NSDS is the model of sustainable development. Theoretically, the sustainable development model of the Republic of Belarus is based on the scientific paradigm of social evolution in an eco-compatible form and includes a set of principles and requirements (imperatives) for the system, the structure of the economy, the mode of functioning and interaction of its subsystems ensuring harmonization of relations in the triad "man - environment- economy "with the goal of a balanced socially oriented, economically efficient and ecological-protective development of the country, meeting the necessary needs of the present and future generations.

The main principles and directions for implementing the environmental policy in the country are defined by the Law of the Republic of Belarus "On Approving the Main Directions of the Domestic and Foreign Policy of the Republic of Belarus" 5, the Law of the Republic of Belarus "On Environmental Protection" 6, the National Security Concept of the Republic of Belarus, the National Strategy for Sustainable Social and Economic Development of the Republic Belarus for the period up to 2020, as well as a number of international treaties of the Republic of Belarus ${ }^{7}$.

The provisions of sustainable development are reflected in the environmental legislation of the Republic of Belarus, and the above-mentioned regulatory legal acts are not an exception. However, a consistent focus on ensuring sustainable development in the system of legislative acts of the Belarusian environmental legislation, however, is not visible.

One of the objectives for achieving the strategic goals of the environmental policy of the Republic of Belarus, such as: creating a favorable environment; improving living conditions and public health; ensuring environmental safety is the development of a system of environmental education and awareness.

The environmental focus of education is the principles of state policy in the field of education, which is enshrined in the Education Code of the Republic of Belarus of January 13, 2011 No. 243-3.

In the light of the concept of sustainable development, the formation of a personality with a certain inner freedom, building its relationship with the environment on the basis of an understanding of its integrity, becomes the ideal of educational systems. Society is called upon to set these qualities through educational systems. Thus, the strategic goal of environmental-legal education is the education of environmental responsibility as a measure of human freedom in terms of environmental necessity.

\footnotetext{
${ }^{5} \mathrm{On}$ approval of the Main Directions of the domestic and foreign policy of the Republic of Belarus: the Law of Rep. Belarus, November 14 2005, № 60-3 // Nat. Register of legal acts Rep. Belarus. 2005. No. 188. 2/1157.

${ }^{6}$ On Environmental Protection: Resp. Law. Belarus, Nov. 26 1992, No. 1982-XII: ed. Law Resp. Belarus of July 17, 2002, N. 126-3 (as amended and added on December 31, 2010, No. 228-3) // Vedamastsi Vyarkhona Saveta Respubliki Belarus. 1993. № 10. - Article 97; Nat Register of legal acts Rep. Belarus. 2002. № 85. 2/875; 2011. № 5. 2/1780.

7The concept of national security of the Republic of Belarus, approved. Decree of the President of Rep. Belarus, 9 Nov. 2010, № 575 // Nat. Register of legal acts Rep. Belarus. 2010. № 1/12080.
} 
The role of authorities would be to regulate the quality and quantity of information to be disseminated and to provide information on existing regulations and market incentives to the public. In establishing such mechanisms, it will be crucial to understand the current status of information received by citizens. The basic understanding of citizens about the environmental issues, the quality and quantity of their knowledge and, over and above, their awareness on environment would constitute an important benchmark for such approaches ${ }^{8}$.

It is global environmental education in general and environmental legal education in particular that contribute to the formation of a new, planetary thinking, a sense of belonging and responsibility for the fate of the planet.

The underlying challenges that sustainability addresses-widespread poverty and growing global environmental degradation-are urgent challenges. Law can make a variety of key contributions in achieving sustainability. We need to find ways to accelerate the use — and analysis — of laws that can foster sustainability ${ }^{9}$.

Environmental education was put forward by UNESCO and the United Nations Environment Program as one of the main means of harmonizing the interaction between man and nature. The Stockholm Conference on the Human Environment (1972) adopted a Recommendation on the creation of an international program on environmental education. By the beginning of 1975, the ball program was developed by UNESCO jointly with the UN Commission on the Environment (UNEP).

The urgent environmental problem and the search for ways to solve it were prerequisites for the creation of a new model of the educational system of the 21 st century. This system should be designed to combine everything positive from the past and the present, and also be focused on the survival of the Belarusian society in the conditions of the environmental crisis, on the formation of a qualitatively new, strong state.

At present, maximum efforts should be made by specialists, including legal scholars, to comprehensively develop a strategy for shaping the ecological culture of the population based on the ideas of sustainable development and sustaining the environment. Therefore, first of all, there is a need to create and disseminate new forms and methods of environmental-legal educational activities.

According to the author, environmental and legal education is a continuous systematized learning process aimed at assimilating knowledge of environmental law, environmental skills, and the formation of a common environmental culture.

Speaking of environmental education in the context of sustainable development, it is also necessary to take into account the distinction between environmental education in general and ecologization of the education system. Despite their interconnectedness, they characterize various phenomena in some respects. Ecological education is the direct assimilation of ecological knowledge of various nature and level. It defines, in particular, the process of training specialists, but is not limited only to this. The ecologization of the education system is a characteristic of the tendency of the penetration of ideas, concepts, and ecology approaches to other disciplines, as well as the preparation of ecologically

\footnotetext{
${ }^{8}$ Role of environmental awareness in achieving sustainable development Economic Commission for Latin America and the Caribbean LC/R.1961 23 November, 2000.

9John C. Dernbach, Joel A. Mintz Environmental Laws and Sustainability: An Introduction Sustainability 2011, 3, 531-540; doi:10.3390/su3030531.
} 
competent specialists in various fields.

Aspect of sustainable development is the idea of promoting "inter-generational equity" making sure that enough of the earth's resources are left to allow future people to meet their needs ${ }^{10}$.

Students of the Faculty of Law of the Yanka Kupala State University of Grodno "is doing a lot of work in the field of environmental education and environmental and legal education of young people. In particular, since 2007, the environmental legal educational action "Living Environmental Law" has been held annually. Law students conduct 2-3 courses in educational institutions of Grodno, the Grodno region, as well as partially outside the informational hours on the topic "Environmental rights and obligations". Within the framework of such events, students, expanding their knowledge in the field of environmental law, present their youth with the principle of "equal teaches equal". Lecturers prepare multimedia presentations, develop tests, conduct business games. Similar and a number of other forms that are developed by the students themselves, contribute to an accessible and effective environmental legal education of young people. These actions, in our opinion, will contribute to the improvement of environmental culture, which is undoubtedly important in the context of ensuring sustainable environmental development of the Republic of Belarus.

\section{Conclusions}

Sustainable development as a legal principle should act not only as one of the main principles of environmental protection, but also as an economic activity, as a result of which, as a rule, there is a negative impact on the environment. The perception of this approach and the use of its corresponding model of sustainable development in an environmental context should be ensured by an effective mechanism of environmental support of economic activities, as well as the inclusion of environmental standards in the acts of legislation regulating the implementation of economic activities.

Sustainable development of society is possible only on the basis of the environmental factor, since environmentally sound socio-economic development can not only be a factor in economic growth, but also ensure environmental security and social stability of the society. The environmental conditionality of the socio-economic development of society requires a conceptual justification of the state policy in the field of environmental protection.

According to the author, environmental legal education should be based on the principles of unity, the historical relationship between nature and society, the social conditionality of the relationship between man and nature, and the desire to harmonize these relations through legal regulations. Ideological work, bringing new values to the national consciousness, through education and enlightenment should convey to each citizen ideas and principles of sustainable development. Moral education and respect for the environment should remain a priority in the media.

\footnotetext{
${ }^{10}$ Important Concepts in Environmental Law - the Idea of "Sustainable Development" https://www.lawnow.org/important-concepts-in-environmental-law-the-idea-of-sustainable-development/ Accessed 05/06/2019
} 
At the present stage of social development and development of law, the concept of sustainable development should be considered as a potentially effective methodological basis of environmental law, as well as other sectors of the Belarusian legal system. Its provisions should be taken into account primarily in environmental and legal science and used in the improvement of environmental legislation.

\section{References}

Avdej A.G. On the legal environmental security of the member states of the Eurasian Economic Union https://elibrary.ru/item.asp?id=27505984 Accessed 05/06/2019

Elaine Nevin Education for Sustainable Development Education and development, 2008, № 6.

Luis A. Avilés Sustainable Development and the Legal Protection of the Environment in Europe /https://pdfs.semanticscholar.org/3fe7/83b8331eb3a0fd5b6a57a7cdcdfc1c03d3f6.pdf Accessed 25/05/2019

John C. Dernbach, Joel A. Mintz Environmental Laws and Sustainability: An Introduction Sustainability 2011, 3, 531-540; doi:10.3390/su3030531

On approval of the Main Directions of the domestic and foreign policy of the Republic of Belarus: the Law of Rep. Belarus, November 14 2005, № 60-3 Nat. Register of legal acts Rep. Belarus, 2005, N 188, $2 / 1157$.

Important Concepts in Environmental Law - the Idea of "Sustainable Development" https://www.lawnow.org/important-concepts-in-environmental-law-the-idea-of-sustainabledevelopment/ Accessed 05/06/2019

On Environmental Protection: Resp. Law. Belarus, Nov. 26 1992, N 1982-XII: ed. Law Resp. Belarus of July 17, 2002, No. 126-3 (as amended and added on December 31, 2010, No. 228-3) Vedamastsi Vyarkhona Saveta Respubliki Belarus, 1993, № 10, Article 97; Nat Register of legal acts Rep. Belarus, 2002, № 85, - 2/875; 2011, № 5, 2/1780.

Role of environmental awareness in achieving sustainable development Economic Commission for Latin America and the Caribbean LC/R.1961 23 November, 2000.

Stepan Wood, Benjamin J. Richardson Environmental Law for Sustainability https://digitalcommons.osgoode.yorku.ca/scholarly works/?utm source=digitalcommons.osgoo de.yorku.ca $\% 2$ Fscholarly works $\% 2 F 337 \& u t m$ medium $=$ PDF\&utm campaign=PDFCoverPages Accessed 01/06/2019

The concept of national security of the Republic of Belarus, approved. Decree of the President of Rep. Belarus, N 9, 2010, № 575 Nat. Register of legal acts Rep. Belarus, 2010, N 1/12080. 